\title{
The Obligation Is the Point
}

\author{
'Refugee 2 Refugee' Care and Solidarity in Greece
}

\author{
Zareena Grewal
}

\begin{abstract}
This article examines how grassroots refugee-activists and 'solidarians' in Greece articulate a collectivist political vision and praxis of care through an expanding network of social obligation that upends narrow understandings of refugees' 'basic' rights and moral obligations of care. The refugees draw on a wide range of universalising collectivist frames including Islamic, Anarcho-Marxist and Palestinian-liberationist frames to articulate visions of solidarity and nurture trust and mutual care amongst refugees.
\end{abstract}

Keywords: activism, Athens, care, charity, NGOs, Palestine, refugees, solidarity

'Apparently, nobody wants to know that contemporary history has created a new kind of human beings - the kind that are put in concentration camps by their foes and in internment camps by their friends'. -H. Arendt, 'We Refugees' (1943)

We encounter Hannah Arendt's observation about refugees from Nazi Germany at a time when there are more refugees than at any time in modern history; more than half of the world's total refugee population is from the Middle East, and most of them are Muslim. To be sure, the oft-used analogy of the 'new Jews' is too crude to apply across vastly different twenty-firstcentury displaced Muslim populations around the world, yet we are witnessing the alignment of global racial orders around different iterations of 'the Muslim question, each with distinct anti-Muslim racist genealogies and histories (Norton 2013). Today, more than a million internally displaced Uighur, Kazakh and other Muslim minorities are corralled in concentration camps in China in the name of security. On the other side of Asia, millions of refugees, most of them Muslims, are fenced in detention camps or languishing without 
asylum or support and concentrated in a bottleneck in Greece and Turkey manufactured by the 2016 European Union-Turkey deal in the name of both a humanitarian response to the so-called 'refugee crisis' and a security response to the so-called 'war on terror'.

Although the United Nations High Commisioner for Refugees' mandate is humanitarian and claims to be non-partisan and apolitical, critical refugee studies scholars who have inherited Michel Foucault's biopolitical framework (2003) have demonstrated the myriad ways in which humanitarian aid and human rights discourses are inherently political, such that the sovereign controls life - fostering, regulating, modulating and managing it through an expanding set of techniques. Achille Mbembe (2003) extends the theorisation of biopower to necropolitics, which exposes subjects to disease and death, including forms of social death. With humanitarian practices and strategies often co-opted by states, humanitarianism operates according to racial logics of (conditional) inclusion of some and the exclusion of others, while rendering the health and even lives of many expendable, which has been referred to as the inherent 'aporia of humanitarian governmentality' (Fassin 2010). With their trained attention to day-to-day experiences, anthropologists distinguish themselves amongst the interdisciplinary scholars associated with the field of critical refugee studies for being particularly apt at capturing the complexity and contradictions of humanitarian work, including how those providing humanitarian and medical assistance to refugees also assume the work of border guards. State officials and NGO workers determine whose pain and suffering deserves an intervention, such as treatment and hospitalisation, and whose does not; which morally legitimate suffering bodies deserve asylum, and which do not; and, in some cases, which bodies become sick and/or die or not (Besteman 2016; Feldman 2007; Inhorn 2018). This 'carceral humanitarianism', as Kelly Oliver (2017) terms it, creates classes of refugees and upholds rather than challenges racism, xenophobia, disaster capitalism and state violence. In the late neoliberal order, refugees are 'rescued' but then sorted, contained within fences and checkpoints, commodified and surveilled in the name of 'crisis' humanitarian care. Of course, Oliver's critique of the European Union's carceral humanitarianism and her attention to the uneasy alliance between humanitarian aid, human rights, and military operations,' which produce refugees as criminals, a societal burden or 'collateral damage', are not simply calls to dispense with humanitarian aid and human rights (2017: 6). Rather, she critiques the calculating machine and lesser-of-evils utilitarian approach to refugees of states and non-governmental organisations (NGOs) in light of Arendt's reminder that 'those who choose the lesser evil forget very quickly that they chose evil' ([1964] 2003: 36). As Miriam Ticktin demonstrates, such humanitarian emergency care engenders systems in which refugees who are apprehended as disabled and traumatised are more welcome than those who are 'merely poor'. Such systems of care also simultaneously produce new forms of state policing and surveillance: 'Harsher security measures [are] pushed 
through under humanitarian pretexts, and victims moved all too easily from endangered to dangerous, innocent to delinquent' (2011: 5).

The slipperiness of this racial logic is perhaps most evident in the collective punishment rationale of deterrence policies which criminalise all migrants. Much like the phrase 'kids in cages', the title 'The Cruelty Is the Point' in Adam Serwer's (2018) article in The Atlantic captured the 'collateral damage' calculus at the root of deterrence policies in the United States, which aim to prevent migration through examples of those suffering and tortured at the border. One of the latest and most gruesome forms of deterrence are illegal 'pushbacks', unprecedented in Greece until Turkey's re-opening of its borders on 27 February 2020 and the COVID pandemic provided a cover for the state's weaponisation of tent-shaped life-rafts. In 2020, human rights groups documented refugees being illegally forced onto rudderless, engine-less life-rafts by Greek authorities, who then abandoned them to die or be discovered by Turkish authorities at the boundary of Turkish and Greek waters, though anthropologists have observed refugees piercing their rafts once they reached Greek shores out of fear of pushbacks for years (Keady-Tabbal and Mann 2020). British-Pakistani novelist Mohsin Hamid caustically argued in The Guardian in 2015 that the militarised detention and the inhumane conditions of the Greek refugee camps are cruel by design but 'not enough' for Fortress Europe:

Simply hardening borders and watching refugees drown offshore or bleed to death on razor wire will not be enough. Europe will have to drastically reduce its attractiveness to refugees. Those who look like refugees will need to be terrorised. They will need to be systematically beaten, rounded up, expelled. Some will need to be killed. The avenues of advancement of those who are not native-born will need to be curtailed by law and by custom - a system of apartheid will need to be instituted. To be of apparent migrant origin in a European country will need to become a fate worse than living in a town or village overrun by bloodthirsty fanatics, by rapacious warlords and thugs.

Such mainstream media representations treat deterrence as a novel and extreme reaction to a 'crisis', a category and condition scholars interrogate. A recent volume, Critical Times in Greece: Anthropological Engagements with the Crisis, edited by Dimitrix Dalakoglou and Georgios Agelopoulos (2018) brings together anthropologists who have been doing long-term fieldwork in Greece in order to examine the impact of the crisis discourse itself. They illustrate how the invocation of crisis often distorts the socio-economic and political transformations taking place in Greece by presenting them as novel. For example, in her chapter, Sarah Green (2018) contrasts the (relatively neutral) older category of the foreigner in Greece against the stigmatised category of the immigrant that developed in the early 1990s in the context of the fall of neighbouring Communist regimes and the consequent sudden mass influx of migrants. Green's analysis of how Middle Eastern refugees came to be seen by many Greeks as literally embodying political crisis (coupled with financial 
crisis) belies official state narratives that treat the sheer numbers of refugees in Greece as a self-evident alibi for carceral policies. Similarly, Giorgos Tsimouris and Roland Moore historicise the slow intensification of Greek Islamophobia and anti-migrant policies including the militarisation of the border as a function of neoliberal austerity measures implemented over a decade. They demonstrate how the cruel racial logics of deterrence echo plainly in a Greek police chief's statement from 2012: 'We must make their lives non-viable, that is they should know, as they come in [the country] they are going to be imprisoned, otherwise we are ineffective, we are becoming the most attractive place for immigrants' (Tsimouris and Moore 2018: 84).

As Katerina Rozakou notes, one of the limitations of the biopolitical framework 'is that it can obscure the complexity of actual practices and the diversity of aid . . Apart from exploring the workings of biopolitical power on the ground, ethnographies need to turn to the cultural notions with which biopolitical schemata are related and transformed' (2012: 565). Rozakou's work is primarily on socialities of solidarity amongst Greek humanitarian workers and the subject formation of the volunteer and/or the 'solidarian', a term with a particular Greek genealogy. ${ }^{1}$ While refugee socialities of solidarity overlap with the Greek examples she describes, I focus on the solidarities and collective praxis-of-care forged by and for refugees in Greece, which are often termed 'Refugee 2 Refugee (R2R)' solidarities. In this article, I examine how grassroots refugee-activists and the solidarians in Greece articulate a collectivist politics of care which expands conventional understandings of refugees' 'basic rights' and the moral obligations of care. They work through a wide range of often overlapping universalising collectivist frames including (1) Islamic; (2) Palestinian-liberationist; and (3) Marxist anti-capitalist frames. Refugees' socialities of care require us to reconsider our assumptions about how 'crisis' conditions make people more likely to act in service of what we too narrowly define as 'self-interest' and to trust others out of necessity (Rubaii 2020). For example, the Islamic causes that refugees in Greece take up amongst themselves often expand normative, secular conceptions of refugees' basic rights, particularly around the religious rights of the dead and the need for Islamic funerary rights (Grewal 2021; Palivos 2018). Whether Islamic, Palestian-liberationist or Marxist, or combinations thereof, refugees' praxes of care draw on universalist conceptions of community and justice as a way to challenge militarised borders and carceral humanitarianism and to imagine better futures for us all.

\section{Methods}

This research is part of a larger multi-site team study on the role of religion in R2R social justice organisations, contexts in which states and NGOs often treat the presence of religion (or religious difference) as a problem to be managed 


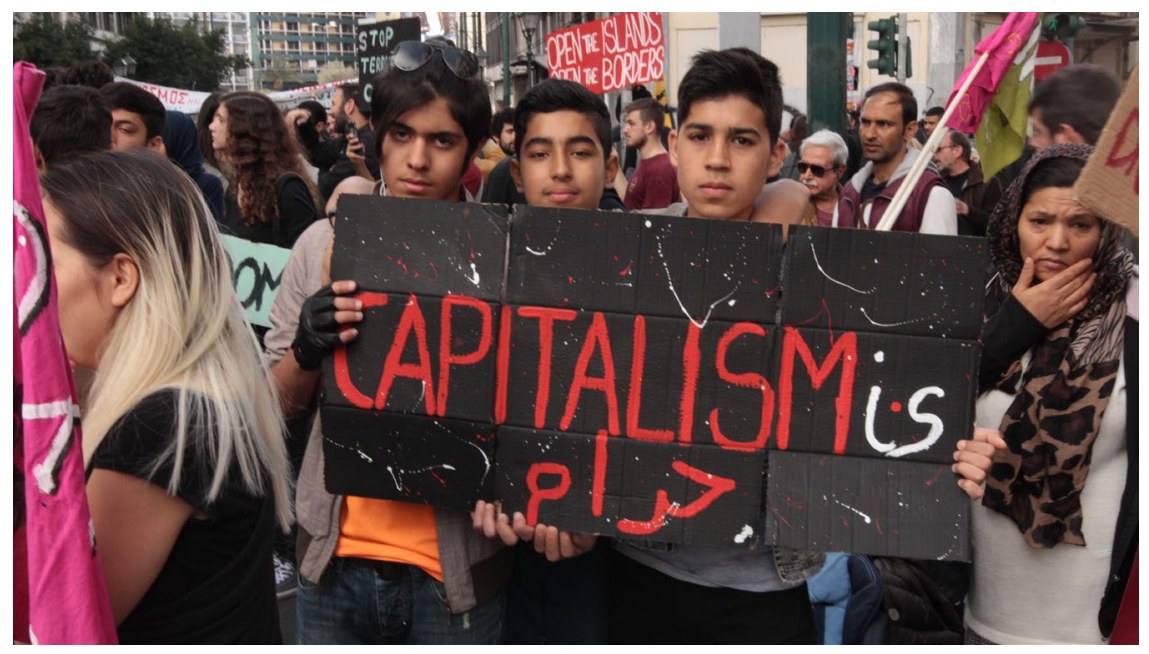

Figure 1: Three boys from the City Plaza squat joined thousands in the streets of Athens protesting the European Union-Turkey deal on 17 March 2018, chanting "Freedom!", “Azadi!", “Fascist Erdogan!” and "Open the borders!" (Photograph by Patrick Sullivan, used with permission).

because it is presumed that religion will obstruct assimilation processes and necessarily result in conflict between refugees (Fiddian-Qasmiyeh et al. 2020). My findings on expansive obligational care networks amongst refugees in Greek borderlands are based on the same pilot study, which was designed to investigate the role of religion in refugee-centered social justice organisations in Greece. I primarily focus on three R2R initiatives in Greece: Jafra-Athens, United Afghan Community in Greece, and City Plaza Initiative in Solidarity to Economic and Political Refugees. Elsewhere I examined the ecumenical ways in which Afghan refugees in Greece mobilise Islamic concepts of baraka (blessings) and the umma (the global community of religious believers) to organise one another to pool meagre resources to support charity and mutual care (Grewal 2021). Despite my focus on religion, I found that Palestinian liberation, human rights and Marxist anti-capitalist critiques were also important registers which Muslim refugees invoked alongside Islamic references in their calls for solidarity and practices of care. For example, on the anniversary of the European Union-Turkey deal, the streets of Athens filled with protesters, amongst them adolescent boys living in an abandoned hotel repurposed as an anarcho-Marxist squat named City Plaza (Lafazani 2017). As they marched, they brandished a large wooden sign that read simply and defiantly: 'Capitalism is haram [sinful]' (Figure 1).

Abolitionist scholar Ruth Wilson Gilmore's (2017) critique of racial capitalist carceral geographies directs our attention to the structural need of economies of abandonment and elite deal-making for 'human sacrifice' in 
necropolitical policies designed to deter immigration. Whether in camps or in ghettos, Gilmore writes that 'criminalization remains a complicated means and process to achieve a simple thing: to enclose people in situations where they are expected, and in many ways compelled, to sicken and die' (2017: 228). Her startlingly simple definition of racism as 'the state-sanctioned and/ or extra-legal production and exploitation of group-differentiated vulnerabilities to premature death' (2002: 261) gestures deliberately at propagated fatalities as an infrastructural requirement of racial capitalist accumulation. Yet Gilmore reminds us that abolitionist critique must not focus exclusively on dispossession but also attend to how people put together social capacities, resources, land and radical consciousness to create "liberated life-ways, however provisional" (2017: 228) that regard life as precious: cultural forms such as the above-mentioned refugees' religio-political protest sign deserve our critical attention.

The material presented on R2R politics and practices of collective care is based on two short research trips to Athens and Lesvos, Greece, in October 2017 and March 2018, during which I conducted 52 structured and semistructured recorded interviews with a snowball sample of Afghan, Palestinian, Yemeni, Syrian, Iraqi and Iranian refugees who live in communities with refugees and provide and/or receive aid. These interviews were supplemented with interviews with solidarians (Greeks and other Western 'voluntourists'). Interview questions were topically focussed on care networks and did not delve into trauma. Informed consent was obtained. Through 2019, I conducted follow-up interviews via WhatsApp with research participants after I (and sometimes they) left Greece. Interviews in Athens were conducted at the organisations' offices or in common spaces in squats or public squares. Interviews in Lesvos were conducted in common spaces or just outside the Kere Tepe, Pikpa and Moria camps. I conducted most of the interviews myself in English or in Arabic, Urdu or Punjabi; however, a few were conducted by my research assistants. All translations are my own. To protect the anonymity and wellness of my interlocutors, I used pseudonyms in some cases.

Anthropologist Heath Cabot (2019) offers a trenchant critique of the ways 'ambulance-chasing' has implicated anthropology as a discipline in the violent, apartheid-like regimes of the 'refugee crisis' in Europe, raising troubling questions about disciplinary relevance, funding structures and a lack of nuanced analysis. She notes that the presence of refugees from the Global South has only recently made Europe a 'hot' field of interest within anthropology. Even for anthropologists who have been working in Greece for a long period of time as she has, the conditions of crisis are what make her work legible to the field at large, betraying a disciplinary politics that too often depends on and reproduces the territorial narratives anthropologists aim to critique and challenge. But Cabot also leaves open the possibility that anthropology can offer 'an attention to deep, locally specific, contextualized knowledge that exceeds the anthropologist's own ways of knowing' (2019: 292). 
Although my time in Greece was short, I see this research aimed at contextualising refugees' obligational networks as a form of the kind of 'patchwork ethnographic processes and protocols' that feminist anthropologists have designed around short-term field visits. Gökce Günel and colleagues (2020) make it clear that 'patchwork ethnography' does not comprise one-time, short, instrumental trips in which ethnographic subjects are treated like consultants; rather, patchwork ethnography must be rooted in research efforts that nurture long-term commitments and depend on 'language proficiency, contextual knowledge, and slow thinking. I see my research in Greek borderlands as part of a larger, multi-year research trajectory that includes my primary field sites in the United States, where I am conducting ongoing research with displaced populations of Muslim Palestinian, Syrian, Iraqi, Iranian, Yemeni and Afghan refugees. I also rely heavily on the secondary literature on the specificities of the Greek context (Cabot 2014). Indeed, my research in Greece would not have been possible without the support and guidance of colleagues who have done years of research in Greek borderlands, particularly Loubna Qutami. Writing against the notion that Palestinians are the exceptional refugee case, Qutami (2020) tracks the multiscalar dispossessions of Palestinian youth and how in Greece young Palestinian refugee-activists at Jafra reconstitute 'kinship, peoplehood, and community beyond the camps they were born into', forging a politics of care and new, expansive communities beyond Palestinians that include Syrian, Iraqi, Afghan, Kurdish and even Greek youth.

\section{The R2R Care Work of Jafra}

Tarek, a Greek-Palestinian activist at the refugee-run NGO Jafra-Athens, explained to me how their grassroots refugee-run organisation sought to provide an alternative to the bloated international (iNGO) humanitarian industrial complex by placing refugees as political actors at the centre of their R2R work:

Jafra is refugee-led and centered; the team working here is entirely composed of refugees and migrants. The ultimate goal is to exercise our agency to provide basic services ... and ensur[e] our identity and sense of belonging isn't lost no matter where our people get dispersed to. The iNGO model depends on the idea that they provide humanitarian assistance in this thing they call 'the refugee crisis' to refugees who can only be passive recipients. The money is the problem ... The consultants, the conferences, the bloated salaries of all those coming from outside, they are only accountable to their donors, never to the refugees they are supposed to be serving. We wanted something self-organised ... so we have a completely different perspective. The issue of [Palestinian] connection to the land is not only an emotional, spiritual thing. It's political. The issue of being a refugee is not only a humanitarian issue. We didn't end up [in Greece] because of floods or earthquakes in Syria or Palestine. We ended up here for political reasons because of war, because of occupation, because of colonialism, because of unjust economic policies toward the Global 
South. So the goal is to provide basic services for our own, by our own, and also strengthen our Palestinian identity to make sure our culture does not get lost no matter where our people get dispersed. And things are possible for our [diasporas] here - you have Palestinians discovering relatives for the first time, we have youth from Lebanon who have never met a '48 Palestinian until they came to Athens.

Since 2017, Jafra-Athens has operated out of a small building in the eclectic Exarchia neighbourhood of Athens, which has a long history of leftist political dissent and collectivist social experiments, a 'heterotopia of resistance' (Chatzidakis 2018). Cafés and bars are filled with co-eds reading and flirting, bookstore windows are lined with works of critical theory and political pamphlets. In a neighbourhood with buildings covered with graffiti deriding the government and celebrating leftist revolutionary icons, the Jafra building did not stand out with its huge poster of the Palestinian martyr and intellectual Bassel AlAraj hanging in the large third-storey window (AlAraj 2013). The center, named in his memory as a symbol of a new era in the long fight for Palestinian liberation, was brightly and freshly painted, clean, but relatively spare with intermittent electricity provided by orange electrical cords from a sympathetic neighbour. On my first visit in 2017, a dozen Jafra staff members, all Arab refugees in their twenties, were scattered about the building. Some studied paperwork over mint tea in a lounge, others assembled a filing cabinet in an office, and two young women conducted Zumba and dabka dance classes in a room that doubled as a daycare space with a SpongeBob SquarePants mural on the far wall and brightly coloured interlocking sponge tiles forming a cushioned floor. The class attracted a dozen more Arab, Afghan and African refugee women whose laughter and music wafted downstairs, some of them residents of Jafra's women's shelter, which was also in the neighbourhood. Empty rooms were arranged as classrooms, and one was being used as a beauty school and salon. One of Jafra's administrators, Amani, a 21-year-old Palestinian Lebanese refugee who had arrived in Greece alone without papers a year earlier, explained the group's inclusive mission:

Our mission is to serve anyone who needs help. Of course, those from Arab countries are most likely to come here because they feel comfortable because we speak Arabic but refugees know we will give whatever we have to anyone who asks. As you can see others do come. We will not ask if they have papers or not or which country or why they came to Greece, no forms, no interrogation. When they come here, it's like a home to them, rather than a service agency. We aren't telling them, 'Fill out this form, sign this document, register. We want everything to be simple for them, for them to enjoy a coffee or tea, to get to know us.

Through care work, Palestinian refugee-activists in Greece profoundly challenge the blanket criminalisation of refugees and carceral humanitarian care of international institutions, legal regimes, corporations, the military and the government. As Qutami notes in her study of Palestinians in Greece: 
Multiscalar dispossession has taught many Palestinians - wherever they grew up that counting on everyday people is their only lifeline. [They] have learned the importance of organizing to maintain the bonds of people to one another and their history and homeland, even and especially in the absence of a state. They rely on the transnational networks, knowledge, resources and past organizational experiences as blueprints or guides in that work, so that their work extends beyond individual quotidian modes of survival and solidarity. (Qutami 2020)

Jafra-Athens serves refugees living in squats throughout Athens as well as those in camps on the Greek mainland and on the islands in the Aegean Sea. JafraLesvos operates unofficially out of a nondescript tent in the infamous Moria refugee camp. Built on a mountainside away from the quaint downtown of the port city of Mytilene, the Moria refugee camp is what the Greek government unofficially deemed a hotspot: camps developed in the wake of the European Union-Turkey deal purportedly as short-term processing centres for the more than one million desperate people who have arrived in Greece since 2015. In fact, they are essentially overcrowded prison camps that human rights groups repeatedly condemn (IOM 2018). Qays, a Palestinian Syrian man who I first met outside Moria and then encountered six months later at the Jafra Center in Athens, explained Jafra's work in Moria and the neighbouring camps in Lesvos:

We started with a tent and called it a 'recreation centre' with activities for the kids which

we were not allowed to do in the camp, so we did things off the books. These people are coming from war-zones; they've suffered a lot of personal trauma [whatever their age]. They survived crossing the sea, which is like walking a line between life and death. We are obligated to help to lighten their burden as much as we can, even if only a little.

The refugees' political ethos and orientation towards collective liberation also insulates them from the kind of internal fracturing perpetuated by carceral humanitarian regimes of care. Tarek explained the universalist foundations of Jafra’s work:

The humanitarian aid system creates a suffering Olympics or fashions in compassion. Before the war in in Syria, there was a focus on Gaza; now there are hardly any NGO jobs in Gaza because it is no longer in fashion and the same will happen to the Syrians. Already the funding for refugees here has been cut in half due to compassion fatigue, donor fatigue. What we try to show is that the issue of Palestine is connected to Syria and always has been connected to Syria, and it was a mistake to talk about Palestine as a single issue separate from the broader region, separate from the rest of the Global South. It's not about fighting for the attention, for the crumbs, but fighting for liberation for everyone. Look at how they arrange camps like Moria in Lesvos; they separate the refugees in the camp by ethnicity, and inevitably this creates conflict and fights and people get hurt. I don't know whether it's a deliberate policy or not, but the result is the same: it divides people and makes them fight over crumbs instead of looking at who is taking the cake. 
Carceral regimes of care reproduce inequalities and create new racial, gendered, ethnic and geopolitical hierarchies in and beyond the camps. Yet the official and deeply racist explanations for why conflicts happen amongst refugees typically pivot around refugees' own innate differences and naturalised prejudices, with officials and volunteers often explaining the violence in the camps as spontaneous examples of misogyny, sectarianism, ethnocentrism, racism, religious bigotry and the cultural defects of the refugees themselves. For example, rather than delivering the same item to all camp residents on the basis of need, camp officials often deliver items on separate days on a nationality-bynationality basis, creating the illusion amongst frustrated refugees of arbitrary hierarchies. Such carceral humanitarian practices in fact manufactured a feeling of being marginalised and excluded amongst those people who were not selected to be the first set of recipients. Lana, an Iraqi Kurdish woman who had had a baby girl a few weeks before I met her in Kere Tepe camp in 2017, suffered from epilepsy and frequently dropped her newborn during seizures. One such sudden seizure in which the baby slipped from her hands happened right before us. Lana and her mother witnessed some refugees receiving strollers, and they tearfully complained that, despite requesting one, they were unable to receive a stroller because they had been reserved for 'Arabs only' I confronted the camp manager of Kere Tepe, the 'family camp' on Lesvos, about her urgent request for a stroller, and he explained to me, matter-of-factly, that 'we can't have a line for strollers - if there is a queue there will be a fight'. In fact, my access to the camp had been conditional on taking his guided tour of the camp first which was punctuated with paternalistic diatribes and an impromptu performance of his favourite song, Frank Sinatra's 'My Way'. When he complained to me of the barbarity and violent nature of Arab men, who routinely beat their wives, I immediately protested, and Qays, the Jafra activist accompanying us, became so incensed that he stormed out of the camp. When I encountered Qays six months later in Jafra's offices in Athens, he recalled his anger over the manager's racist characterisations of Arab men vividly. Qays had just married celebrated Palestinian activist, lawyer, and political prisoner Shireen Issawi, who he met at a university in Athens after her lecture about being persecuted, imprisoned and debarred from practicing in Israel simply for doing her job advocating for Palestinian prisoners' rights (Hassan 2017). Being newly-wed and in love made the memory of the manager's racist insinuations about violent Arab husbands that much more cutting.

\section{The Obligation Is the Point: Refugee Solidarity in the Moria Camp}

Manar confessed to me she wished that she had been deterred from crossing the sea from Turkey to Lesvos when we spoke outside of the infamous Moria camp. With her back to Moria's entrance, where someone had spraypainted 
'Welcome to reria Prison', she swore vehemently: 'If I knew it was going to be like this, I would not have come'. When I met Manar, she was both a refugee living in Moria and a service provider employed by the Red Cross to work in the camp and as a children's tutor in a nearby recreation centre called One Happy Family, due to her excellent command of English. She had already had a career working with human rights iNGOs in Yemen as a translator, bookkeeper and administrator. Trained as an electrical engineer, Manar fled her war-torn homeland once she became a target of Al-Qaeda for her work in Aden as a research assistant for iNGOs and United Nations officials. After a death threat in the form of an ominous WhatsApp message, her mother told her: 'There is a life for you somewhere, I am sure it is not here'. Her mother and grandmother financially supported Manar, encouraging her to join another young Yemeni woman who had fled to Turkey. Reunited with her friend Dona in Turkey, Manar struggled to find work and to learn the Turkish language. She found that few Turks spoke English, and she worried that she and her roommate Dona were quickly spending through their savings. After several difficult months, they decided to try to travel to Greece over the Aegean Sea, and paid a smuggler 1,000 euros. She was told that her journey to Lesvos would only be a few hours by boat, but even after eight terrifying hours at sea her overcrowded boat had to be rescued by a Frontex boat. When the rescue boat finally met the Greek shore, Manar burst into relieved tears. Her relief was short-lived. She burst into tears again once Frontex volunteers, acting as quasi-border guards, delivered them to be processed at Moria.

At the time, Manar was one of more than 6,000 refugees living in Moria, about triple its capacity of 2,330 people. Although its razor-wire fence was patrolled by armed guards, there were large holes facing the olive groves through which refugees could enter and exit the camp's compound. Overflow camps of flimsy tents clung to the wooded mountainside outside the military complex that Moria camp was built on. The morning of my first visit to Moria another 150 people survived the risky sea journey and arrived on the island's beaches as Manar had months earlier, and rumors of their immediate deportations circled through the camp.

As Manar waited to be processed at the Moria camp on her first morning, she befriended a young Palestinian Syrian man named Aala who had been on her boat and who offered her a shady spot to sit in. Aala grew up in Yarmouk, a Palestinian refugee camp outside of Damascus, which was home to more than 100,000 refugees before the Syrian War. Aala was a university student when the war started in Damascus and lost two of his older brothers. One was killed when a bomb hit their home, and the other was shot by Syrian police right before his eyes. Mourning his brothers and wanting to avoid the mandatory military draft of the Syrian government, Aala and his family hired a smuggler for 1,400 euros to get him to Turkey and then to Lesvos, Greece, a journey especially terrifying for him because Aala cannot swim. Like Manar, Aala's charisma and command of English quickly made him a natural leader in the 
camp, where he was also employed by the Red Cross. It was an open secret that he was simultaneously working for Jafra, which does not have official sanction to work with the camp, but covertly shares supplies mailed by the Athens office to Moria's residents: supplies consisted of food, hot and cold packets, toys, sleeping bags, hygiene kits, gloves, clothes and even cigarettes. The day I met him outside of Moria, Aala approached Manar and me from behind with an impression of Michael Keaton, 'I'm Batman', and he playfully puffed up his chest under his black t-shirt emblazoned with the Batman logo.

A deep friendship bloomed between Aala and Manar in Moria, surprising both of them as well as many on-lookers in the camp, as close platonic friendships between adult men and women are relatively unusual in the Middle East, and certainly the first for either of them (though Aala jokingly assured me that he had had plenty of girlfriends). Perhaps for the benefit of those who might mistake their constant, gentle teasing as flirting, their jokes about their futures eliminated the possibility of romance between them: they mock-fought over who would have better-looking children, they fantasised about ending up in different countries (including a future liberated Palestine) so that they could host one another's families for vacations; they played out comical scenarios in which they reassured future spouses threatened by the strength of their bond. 'Sometimes you feel like yourself again with this connection', Manar said. She found that she could not go long without seeing him. 'We need to see each other, talk to each other. [My female roommates] are my best friends but I also need Aala and Aala needs me'. Aala explained that he could be vulnerable with Manar, too, and that whenever he became depressed she pulled him out of it and that he did the same for her. They also worked as a team in supporting others in the camp, organising impromptu dance-offs or common cookouts as an alternative to the terrible food served by the camp.

Aala had a dark running joke with Manar about her roommates, who had received their asylum papers months ago but had decided to stay in Moria until Manar, too, could come with them. He joked about a day that would soon come when they would tire of the torturous waiting and disgusting conditions in the camp and change their minds, leaving her behind. Every time a sad breakup song came in earshot, Aala jokingly mused that he would play it for Manar as he and her roommates drove off in the bus to the ferry for their new lives in Athens, waving to a tearful, paperless Manar from the bus window. Manar feigned anger but she insisted her friend Dona would not leave without her and that she was confident that even Aala, for all his jokes, would be as loyal as her real younger brother, who she left behind in Yemen. 'Aala would never admit it', Manar swore, 'but he would never leave without me'. A month later, Aala got his asylum papers after waiting for almost a year, but because Manar did not receive hers he, like her roommates, remained in Moria for her until she finally got her papers to go to Athens a few months later.

Such stories of deep friendships and fictive kinship born out of the shared trauma of living in the camps are surprisingly common, although such care 
practices may strike many as incredulous choices, given the truly inhumane conditions of the camps. Why would anyone choose to prolong internment in such squalid living conditions? The power of the deep and abiding sense of obligation, concern and loving sacrifice between refugees in the camps stands in stark contrast to its carceral regimes of care and its cruel calculus, which treat refugees as collateral damage. As Manar put it, 'the only beautiful thing I found in Moria is friendship.

Manar remained detained in Moria for months after Aala's asylum papers were granted, and he remained with her unwavering, but they often discussed the incoherence of how the accidents of where they were born determined their different outcomes. Unlike those fleeing the wars in Syria or Iraq or Afghanistan, those fleeing the fighting in Yemen were not granted refugee status by the European Union because the latter was not directly involved in the Yemeni conflict. Even though Manar's warmth and charisma made it easy for her to connect to people, and even though she developed a close network of friends inside the Moria camp, she felt vulnerable as a single woman. Fights routinely break out between the men in camps such as Moria, particularly along ethnic and national lines, and Manar reported rampant sexual harassment, which, she noted angrily, the police and guards usually ignored. Her friendship with Aala acted as a partial, protective insulation in dangerous situations the way the presence of a male relative might. As I was interviewing Manar a few kilometres from the camp, a fistfight broke out within the Moria camp and escalated to the point that a Syrian man stabbed an Afghan man with a makeshift knife. Aid workers immediately evacuated the camp, but the police did nothing to make the refugees feel safe and secure. Manar noted sadly that such fights between refugees were an almost weekly occurrence, fueled by close quarters, boredom and drugs and alcohol, and that in some instances the guards punished everyone in the overcrowded camp collectively with raids and teargas. That day, the police only collected the stabbed man once the refugees had intervened and calmed the situation down: 'The police vanish [during fights] and the European relief workers run out. We have to handle [these violent men] ourselves'.

In such moments of physical danger and fear, as all of the white aid workers and volunteers (and researchers) immediately evacuate the camp, Manar and Aala become painfully aware that for all their jokes about feeling like VIPs in their Red Cross vests, whatever social privileges accrued with working with the iNGO are ephemeral. This is why an affiliation with Jafra (which transcends the temporality of the current 'crisis' and the space of the camp) is so meaningful to many refugees. That evening, Manar and Aala joined about 200 Afghan refugees surrounding the perimeter of the camp in a sit-in which lasted for three days and nights, chanting 'Moria is not safe!' as the police only watched from a tense distance. The next day, the protesters marched to downtown Myteline. A few weeks later, the mayor of Lesvos joined a refugee protest downtown after filing what was seen as a largely symbolic lawsuit against the 
Greek military for mismanaging the Moria camp. He accused the Greek government of turning the island, a renowned vacation destination, into a torturous spectacle, the 'Guantanamo Bay of Europe'.

\section{'The Best Hotel in Europe': Mutual Care in the City Plaza Initiative in Solidarity to Economic and Political Refugees}

Weeks after the European Union-Turkey deal was signed, on 22 April 2016, over 100 solidarians and 120 refugees broke into an abandoned seven-storey Athens hotel and reconnected the utilities. City Plaza Hotel was shuttered in 2010 in the wake of the financial crisis. The building is located in one of the most politically conservative neighbourhoods in Athens, Aghios Panteleimonas, which was a stronghold of the fascist Golden Dawn Party from 2008 until 2013, and in 2016 fascist gangs were still a strong presence. In fact, neighbours threatened to call the police or the local fascist gangs to kick the refugees and solidarians out. The squatters peacefully resisted, making human chains around the building and ultimately established a thriving shelter for refugees for two-and-a-half years. By the time the City Plaza community collectively decided to close on 10 July 2019, they claimed that 2,500 refugees from 13 countries had called it home. On its Facebok page, the tongue-in-cheek tagline read: 'No pool, no minibar, no room service, and nonetheless, the Best Hotel in Europe!'

When I first visited City Plaza and another squat called the 5th School in 2017 and 2018, they were 2 of 15 such abandoned buildings in Athens that had been forcibly repurposed as refugee shelters, all forced to close in 2019. In contrast to 5th school, where the living conditions were dismal, City Plaza resembled a radically egalitarian co-op, with the energy and aesthetic of a college dorm: cheap furniture, music from competing speakers, walls lined with political posters and children's artwork, and sign-up sheets for an open mic night and shifts in the kitchen. Large portraits throughout the building featured the faces of the residents passing before me: men and women who chatted in Farsi, Arabic, Urdu and English. Muhannad, a Syrian refugee who had been living in City Plaza for over a year, explained that he would be homeless, languishing in Athens' streets, waiting to be processed had it not been for City Plaza. He described the accommodations and warm friendships he developed in City Plaza with Kurdish, Pakistani and Iraqi young men to his Syrian friends stuck in the camps on Lesvos by phone. 'When they call and ask, "Where are you now?", I [used to] say City Plaza. But now I just say "I'm home". It is the only place that felt like a home since I left Syria three years ago, nothing like it in Lebanon, Irbil, Turkey'. Still Muhannad hoped for a permanent home with his brother in Germany.

Elpida, one of the Greek leftist founders of City Plaza, explained that new refugee residents are told upfront that City Plaza is a squat, but that some of the refugees come to see the value of their radically egalitarian project slowly. She 
described an early morning when the water company arrived to shut off their water and they woke all of the residents and made a human chain on the sidewalk to prevent company personnel from entering. It was a small, if temporary, victory: the water stayed on. 'Then', she said, 'the refugees really understood that it's not a [shelter] from the state. She described City Plaza as one political struggle connected to global struggles for justice: 'For me, City Plaza is a part of a much wider struggle against borders, against capitalism, against any kind of exclusion. And this is inspiring for me, but I think [some of the refugees] might have completely different things that inspire them and that's fine'.

Thirty-year-old Reza was, in fact, attracted to City Plaza because of its radical leftist political orientation. Born in an Iranian prison to parents who are political dissidents, Reza did not need to come to Greece for a leftist political education. In Iran, his feminist activism and advocacy for children's and Afghan refugees' rights put his life in danger repeatedly; the government persecution he faced was exacerbated by his participation in the 2009 protests of the Green movement. Fleeing to Turkey, Reza worked for a feminist NGO and as a freelance journalist for various leftist papers for several years until he was targeted in a government crackdown. After a brief but brutal stint in a Turkish prison, Reza fled to Greece in 2017. Fluent in four languages and holding a degree in archaeology, Reza felt right at home in the multi-lingual, multiethnic and multi-national intentional community that was City Plaza: 'I don't believe in countries, borders. The nice thing about this community is we are all different but together, united. When another refugee or anyone asks, "Where are you from?" we say, "I am from City Plaza". This is our country, our family. We care for one another'.

At City Plaza, Reza played numerous roles including that of a teacher for elementary-school-aged children. He marvelled at how quickly he grew attached to them. When I asked him if he, as an atheist, felt uncomfortable living in such close proximity to so many observant Muslims after suffering torture at the hands of Islamists in Iran and Turkey, he was vehement: 'For me religion is the source of so many problems. In Iran, I fought with women to not have to cover because the Islamic state is a murderous state, a fascist state. In Greece, it is the racists who hate the women in hijab, and I will fight against the racists for their right to choose to wear it. The idea is the same: freedom. But I still don't like when the hijab is used as a symbol of resistance because I know it is used as a tool for shame in Iran; even leftist women in Iran, my own relatives, feel ashamed without the hijab after they forced it for so many years.' Unlike the camps, the squats I visited were not rife with ethnic or political conflict between refugees but were remarkably diverse, relatively harmonious - if imperfect - communities (I encountered one Iranian couple who left City Plaza due to a bedbug infestation and preferred the Malakasa camp). At City Plaza, most of the conflicts amongst the residents were not over their differences but over mundane 'chore wars'. 
Reza's least favourite chore was running City Plaza's front desk and managing the long waitlist. Reza had just turned away two enquiring Iranian and Iraqi families. He himself had been turned away from the squat when he was living on the streets of Athens three months earlier, but he kept returning until a room opened up. 'I wish I had a plane to take each and every one of these people to the places they want to go. I wish I could become a bird and carry them to other countries'. Still, Reza insisted he believed deeply in the mission despite the painful dimensions of the squat community's pragmatic self-governance; anthropologists have challenged any sharp division between the camps and squats by highlighting how pragmatic calculations and various forms of care work characterise both squats and camps. ${ }^{2}$ Preserving the limit of 400 persons that the building could comfortably accommodate was one of the founding principles of the City Plaza collective, a rule enforced even when desperate, homeless refugees came to the front desk and attempted to barter for a small corner in a common area. Elpida explained: 'We're in the difficult position of saying no. [If] we put 1,000 people here then actually the conditions here will be similar to a camp. We wouldn't have solved the problem, because there are another 60,000 refugees in Greece in camps'.

Ali, an Afghan man and solidarian who settled in Greece in 2000, explained that the vision of City Plaza was never to rescue homeless refugees: 'Our political work is scandalising the policies and practices of the EU and the Greek government and even the NGOs, the way that they work with refugees and create a pathetic population of dependency on the state. City Plaza had a small set of individual donors but accepted no money from NGOs, religious organisations or any government. Against the state's valorisation (and manufacturing) of refugee helplessness, the solidarians of City Plaza make no claim to have 'taken care' of the approximately 400 people who lived there at any given time. Ali explained: 'Refugees do it by themselves. They are very strong people. They managed to arrive here. They escaped wars. They can organise a house like this themselves'.

Without overstating the categorical material differences between squats and camps, my interviews and observations in the camps reveal important differences in how refugees are talked about. In interviews, some camp officials and professional humanitarian service providers in the camps operated with the racist assumption that refugees are 'naturally' predisposed towards discord, intolerance and violence. In the camps in Lesvos, it was assumed that there would naturally be competition, tension and even violent clashes due to the close proximity of refugees who identified with different nationalities, religious movements and sects, ethnic and racial groups; violence against women and queer refugees was also treated as inevitable. Racist presumptions about how social constructions of difference operated as fault lines, creating spontaneous conflicts along the lines of ethnicity, nationality, and sect shaped how carceral humanitarian regimes delivered resources to refugees. Ali described the 
peaceful conditions of City Plaza as normal in contrast to the abnormal conditions of the camps with their manufactured scarcity and conflict:

In Lesvos, in Moria they bring to a camp of 7,000 people 5,000 plates of food [as if to say] the one who is powerful will eat, the one who belongs to this category will eat, and the others, they will not eat. This is like the rule of the jungle. Hunger, sadness, happiness do not [know] any colour, any religion. If you are hungry no matter where you are coming from, you need food and if you are a man with five children and they need food and it is very limited you will go to fight to get food to feed your children. This is how they create the image of crisis and bad [refugees]. After leaving the camps and coming to City Plaza the same people become again normal people. They don't fight because there is no reason to fight for food. They don't live in tents or feel uncomfortable. Here the people have rooms, and the rooms have doors with a lock, and they have a key. They have a toilet and shower in their room. These are the basic needs of people, but they don't provide for them in the camps.

Elpida does not want their vision to be reduced to finding a more humane response to the refugee crisis - merely demonstrating a better humanitarianism. She wants it to be seen as offering an 'antagonistic political example' to shame the state and the NGOs for their carceral humanitarianism:

If we can do it without institutional funding, without any kind of resources from the state or from the NGOs, without any of us being employed here, just with people who offer their time - no specialists - then the fact that the NGOs and the state are not doing [it proves] they choose to have the camps. It is not that they cannot do [better], it's that they do not want to do it. They want people to be excluded socially, spatially, to be kept in an inferior position.

Squats such as City Plaza pointedly and publicly pose the question of whether the core capitalist value of private land ownership should take precedence over the need to meet people's basic human rights to shelter, water and food. And refugees are posing these questions and critiques amongst themselves and in their own registers. Reza observed: 'The situation in Greece looks like [the prison movie] Shawshank [Redemption]. ${ }^{3}$ They want to take your hope, everything. But when everything comes from the heart, they cannot take it'.

\section{Conclusion: To Set the World Right}

Refugees in Greece resist the objectification and criminalisation of their lives through their day-to-day collectivist care work and political organising and through their expansive understanding of social obligations and community that are the basis for their socialities of solidarity. While Islamic, Palestinianliberationist and anti-capitalist-Marxist resistance traditions have their own internal debates and important differences and tensions, my focus here has been on how such collectivist framing can co-mingle and overlap in refugees' 


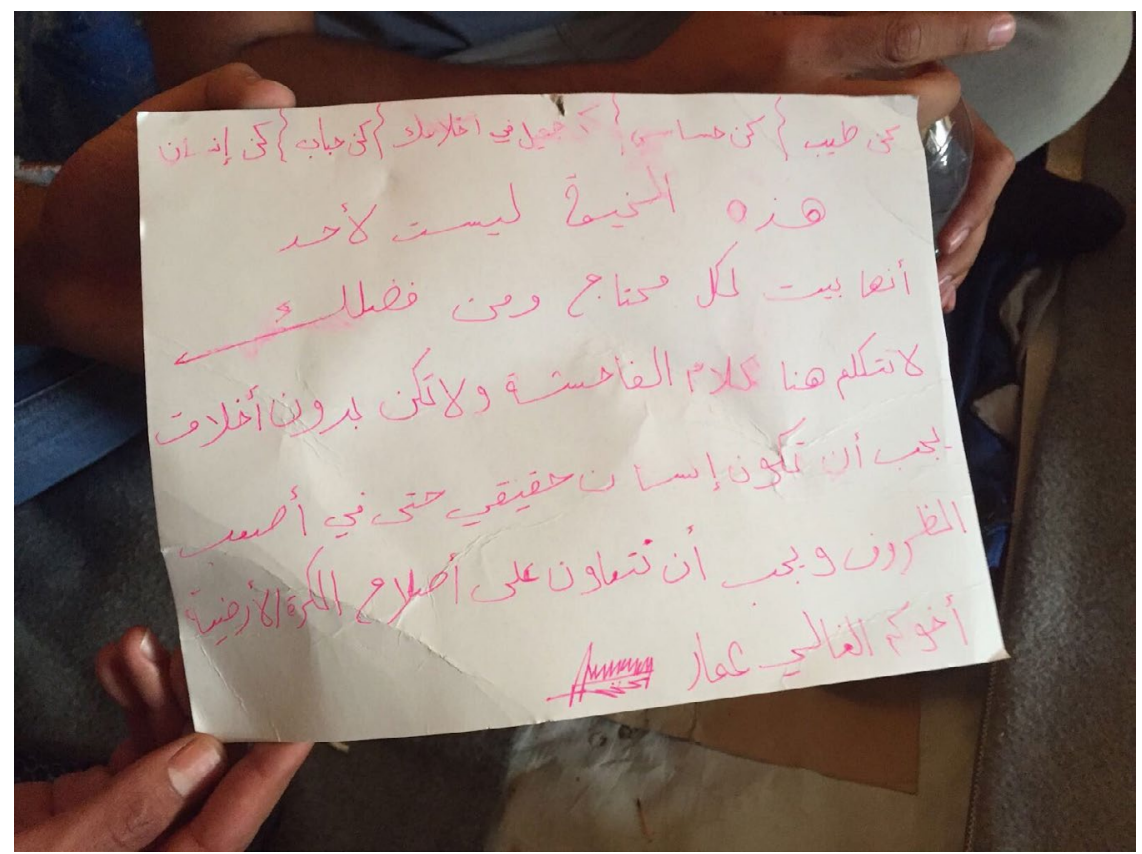

Figure 2: A handmade sign of rules for living hung in Moria 'overflow' encampment. (Photograph by Nat Wyatt, used with permission).

praxis of collectivist care. Anthropologists must pay attention to spectacular political forms and practices as well as the seemingly mundane, everyday work of collective solidarity. In a small tent in the overflow camp outside of Moria, a handmade sign of 'golden rules' reads as follows (Figure 2):

Be good. Be sensitive. Be well mannered. Be loving. Be humane. This tent is not the property of any one person. It is a home for anyone in need. Please don't speak ill here or be ill-mannered. You must be a real, genuine person even under difficult circumstances. We must cooperate with one another to set the world right.

The message of this sign is not explicitly Islamic (though its tone and language could be read that way); it makes no mention of specific liberation struggles as part of setting the world right (though that too might be one reading); and in claiming the space of the tent as a commons, it may or may not have been intended as a critique of capitalism, private property and national borders. Whatever the original intent behind its commands, the sign constitutes an invitation to imagine a world set right, to make the work of living together the very care work needed to set the world right. 


\section{Acknowledgements}

I thank my research assistants Frances Fagan, Maysan Haydar and Patrick Sullivan and all of the research participants who agreed to be interviewed. Special thanks to Loubna Qutami for her support throughout. This research was supported by grants from the Luce Foundation.

Zareena Grewal is an Associate Professor of American Studies, Religious Studies, Anthropology and Ethnicity, Race, and Migration at Yale University. Her first book, Islam Is a Foreign Country: American Muslims and the Global Crisis of Authority (NYU Press 2014), is a historical ethnography, based on fieldwork in Egypt, Jordan and Syria, of transnational Muslim intentional communities and intellectual networks that link US mosques to Islamic movements in the post-colonial Middle East through debates about religious reform and Islamic utopias. She is currently working on a book on the social life of the Quran as a racialised text-object at the center of the culture wars in the United States. Email: zareena.grewal@yale.edu

\section{Notes}

1. Rozakou historicises solidarians' solidarity in a longer anti-authoritarian anarchist movement that later merges with pro-immigrant movements and also considers the cooptation of the term by humanitarian workers (Rozakou 2016a, 2016b, 2018). Fascists and neo-Nazis have their own racist and nationalist solidarity movements, with their soup kitchens and organizations such as 'Doctors with Borders' providing care services to 'pure' Greeks (Bampilis 2018).

2. Squats can actually turn into de facto advanced 'schools' in humanitarian work as solidarians and refugees alike find themselves working side by side with professional humanitarian workers and NGO officials and even celebrities (Papataxiarchis 2018). For example, I made visits to City Plaza, 5th School, and Pikpa during the same period as the X Factor's Bradley White-Dale and public intellectuals such as Angela Davis, Wendy Brown and Judith Butler.

3. The Shawshank Redemption (1994) was directed by Frank Durabont and distributed by Columbia Pictures. 


\section{References}

AlAraj, B. (2013), 'Al-sha'bu Yureed-u Majlis-an waTaniyy-an Jadeed-an (The people demand a new national body)', 30 March, https://web.archive.org/web/ 20170720203112/https://www.qudsn.ps/article/6114 (accessed 14 January 2021).

Arendt, H. [1943] (1994), 'We Refugees', in Altogether Elsewhere: Writers in Exile, (ed.) M. Robinson (Boston: Faber and Faber), 110-119.

Arendt, H. [1964] (2003), 'Personal Responsibility under Dictatorship', in Responsibility and Judgment, (ed.) J. Kohne (New York: Schoken Books), 17-48.

Bampilis, T. (2018), 'Far-right Extremism in the City of Athens during the Greek Crisis', in Critical Times in Greece: Anthropological Engagements with the Crisis, (ed.) D. Dalakoglou and G. Agelopoulos (New York: Routledge), 59-72.

Besteman, C. (2016), Making Refuge: Somali Bantu Refugees and Lewiston, Maine (Durham, NC: Duke University Press).

Cabot, H. (2014), On the Doorstep of Europe: Asylum and Citizenship in Greece (Philadelphia: University of Pennsylvania Press).

Cabot, H. (2019), 'The Business of Anthropology and the European Refugee Regime', American Ethnologist 46, no. 3: 261-275, https://anthrosource.onlinelibrary.wiley. com/doi/10.1111/amet.12791.

Dalakoglou, D. and Agelopoulos, G. (eds) (2018), Critical Times in Greece: Anthropological Engagements with the Crisis (New York: Routledge).

Fassin, D. (2010), 'Inequality of Lives, Hierarchies of Humanity: Moral Commitments and Ethical Dilemmas of Humanitarianism', in In the Name of Humanity: The Government of Threat and Care, (ed.) I. Feldman and M. Ticktin (Durham, NC: Duke University Press), 238-255.

Feldman, I. (2007), 'The Quaker Way: Ethical Labor and Humanitarian Relief', American Ethnologist 34, no. 4: 689-705, doi:10.1525/ae.2007.34.4.689.

Fiddian-Qasmiyeh, E., Grewal, Z., Karunakara, U., Greatrick, A., Ager, A., PanterBrick, C. . . . and Rowlands, A. (2020), Religion and Social Justice for Refugees: Insights from Cameroon, Greece, Jordan, Lebanon, Malaysia and Mexico, March (London: University College London), https://refugeehosts.files.wordpress.com/ 2020/04/bc-hl-religion-and-social-justice-for-refugees-report-hr.pdf.

Foucault, M. (2003), 'Society Must Be Defended': Lectures at the College de France, 1975-1976 (London: Penguin).

Gilmore, R. (2002), 'Race and Globalization', in Geographies of Global Change: Remapping the World, (ed.) R. J. Johnston, P. Taylor and M. Watts (New York: WileyBlackwell), 261-274.

Gilmore, R. (2017), 'Abolition Geography and the Problem of Innocence', in Futures of Black Radicalism, (ed.) G. T. Johnson and A. Lubin (New York: Verso), 225-240.

Green, S. (2018), 'Crisis within a Crisis? Foreigners in Athens and Traces of Transnational Relations and Separations', in Critical Times in Greece: Anthropological Engagements with the Crisis, (ed.) D. Dalakoglou and G. Agelopoulos (New York: Routledge), 102-116. 
Grewal, Z. (2021), 'Race, Religion, and Afghan Refugees' Practices of Care in Greece', in Un-Settling Middle Eastern Refugees: Regimes of Exclusion and Inclusion in the Middle East, Europe and North America, (ed.) M. C. Inhorn and L. Volk (New York: Berghahn).

Günel, G., Varma, S. and Watanabe, C. (2020), 'A Manifesto for Patchwork Ethnography', Society for Cultural Anthropology, 9 June, https://culanth.org/fieldsights/ a-manifesto-for-patchwork-ethnography.

Hamid, M. (2015), “The Turmoil of Today's World," The Guardian, 12 September, https://www.theguardian.com/books/2015/sep/12/the-turmoil-of-todaysworld-leading-writers-respond-to-the-refugee-crisis.

Hassan, B. (2017), 'Raised to Rebel', Electronic Intifada, 13 November, https:// electronicintifada.net/content/raised-rebel/22261 (accessed 14 January 2021).

Inhorn, M. C. (2018), America's Arab Refugees: Vulnerability and Health on the Margins (Stanford, CA: Stanford University Press).

IOM (International Organization of Migration) (2018), 'Mediterranean Migrant Arrivals Reach 20,927 in 2018; Deaths Reach 587', International Organization of Migration, 27 April, https://www.iom.int/news/mediterranean-migrant-arrivalsreach-20927-2018-deaths-reach-587.

Keady-Tabbal, N. and Mann, I. (2020), 'Tents at Sea: How Greek Officials Use Rescue Equipment for Illegal Deportations', Justsecurity, 22 May, https://www.justsecurity. org/70309/tents-at-sea-how-greek-officials-use-rescue-equipment-for-illegaldeportations/.

Lafazani, O. (2017), 'Intervention-1.5 Year City Plaza: A Project on the Antipodes of Bordering and Control Policies', Antipode Online, 13 November. https:// antipodeonline.org/2017/11/13/intervention-city-plaza/ (accessed 14 January 2021).

Mbembe, A. (2003), 'Necropolitics', Public Culture 15, no. 1: 11-40, doi:10.1215/ 08992363-15-1-11.

Norton, A. (2013), On the Muslim Question (Princeton, NJ: Princeton University Press).

Oliver, K. (2017), Carceral Humanitarianism (Minneapolis: University of Minnesota Press).

Palivos, T. (2018), 'Moral Masculine Intimacy: The Care and Protection of the Living and the Dead among Muslim Migrant Men Living in Greece', in Reconceiving Muslim Men: Love and Marriage, Family and Care in Precarious Times, (ed.) M. C. Inhorn and N. Naguib (New York: Berghahn), 262-278.

Papataxiarchis, E. (2018), 'Pragmatism against Austerity: Greek Society, Politics, and Ethnography in Times of Trouble,' in Critical Times in Greece: Anthropological Engagements with the Crisis, (ed.) D. Dalakoglou and G. Agelopoulos (New York: Routledge), 227-247.

Qutami, L. (2020), “'The Camp Is My Nationality”: Palestinian Situated Knowledge in the Global Refugee Crisis', Critical Ethnic Studies 6, no. 2.

Rozakou, K. (2012), 'The Biopolitics of Hospitality in Greece: Humanitarianism and the Management of Refugees', American Ethnologist 39, no. 3: 562-577, doi:10.1111/j.1548-1425.2012.01381.x. 
Rozakou, K. (2016a), 'Crafting the Volunteer: Voluntary Associations and the Reformation of Sociality', Journal of Modern Greek Studies 34: 79-102, doi:10.1353/ mgs.2016.0014.

Rozakou, K. (2016b), 'Socialities of Solidarity: Revisiting the Gift Taboo in Times of Crises', Social Anthropology 24, no. 2: 185-199, doi:10.1111/1469-8676.12305.

Rozakou, K. (2018), 'Solidarians in the Land of Xenios Zeus: Migrant Deportability and the Radicalization of Solidarity', in Critical Times in Greece: Anthropological Engagements with the Crisis, (ed.) D. Dalakoglou and G. Agelopoulos (New York: Routledge), 188-201.

Rubaii, K. (2020), 'Trust without Confidence: Moving Medicine with Dirty Hands', Cultural Anthropology 35, no. 2: 211-217, doi:10.14506/ca35.2.03.

Serwer, A. (2018), 'The Cruelty Is the Point,' The Atlantic, 3 October. https://www. theatlantic.com/ideas/archive/2018/10/the-cruelty-is-the-point/572104/.

Ticktin, M. (2011), Casualties of Care: Immigration and the Politics of Humanitarianism in France (Berkeley: University of California Press).

Tsimouris, G. and Moore, R. (2018), 'Death in the Greek Territorial and Symbolic Borders: Anti-Immigrant Action for Policing the Crisis', in Critical Times in Greece: Anthropological Engagements with the Crisis, (ed.) D. Dalakoglou and G. Agelopoulos (New York: Routledge), 73-85. 